\title{
Effects of adding a concentrated pomegranate-residue extract to the ration of lactating cows on in vivo digestibility and profile of rumen bacterial population
}

\author{
E. Jami, ${ }^{*} \dagger$ A. Shabtay, ${ }^{*}$ M. Nikbachat, ${ }^{*}$ E. Yosef, ${ }^{*}$ J. Miron, ${ }^{*}$ and I. Mizrahi ${ }^{* 1}$ \\ ${ }^{*}$ Department of Ruminant Sciences, Institute of Animal Science, Agricultural Research Organization, PO Box 6, Bet-Dagan 50250, Israel \\ †Department of Molecular Microbiology and Biotechnology, The George S. Wise Faculty of Life Sciences, Tel Aviv University, \\ Ramat-Aviv 69978, Israel
}

\begin{abstract}
This study characterizes the effects of concentrated pomegranate-peel extract (CPE) addition to the TMR at levels of 1,2 , or $4 \%$ on voluntary intake, in vivo digestibility, milk yield and composition, and profile of rumen bacterial and archaeal populations in lactating Holstein cows. Supplementation of CPE significantly affected the abundance of methanogenic archaea and specific ruminal bacterial species related to cellulolytic activities and soluble sugar and lactic acid fermentation, as revealed by real-time PCR quantification. Furthermore, CPE supplementation had a significant dose-dependent effect on the whole ruminal bacterial community, as determined by automated ribosomal intergenic spacer analysis. These changes were accompanied by a significant increase in digestibility of dry matter, crude protein, and neutral detergent fiber, as well as milk and energy-corrected milk yields in cows fed the $4 \%$ CPE supplement. These results suggest that CPE supplementation significantly affects the rumen bacterial communities, which in turn may be related to a beneficial effect on dairy cow performance.
\end{abstract}

Key words: pomegranate-residue extract, lactating cow, rumen bacterial population, digestibility and performance

\section{INTRODUCTION}

Global production and consumption of pomegranate has greatly increased in recent years, together with recognition of the health-promoting potential of various components in this fruit (Aviram et al., 2008). Accordingly, until 2010, 2,800 ha of pomegranate trees were planted in Israel. This expanding trend has led to the development of advanced industrial technologies that provide consumers with "ready to eat" pomegranate

Received March 13, 2012.

Accepted May 27, 2012.

${ }^{1}$ Corresponding author: itzhakm@agri.gov.il arils and with fresh fruit juices. These advances are expected to lead to the accumulation of high quantities of active pomegranate biomass. Pomegranate components have attracted attention for their apparent wound-healing properties (Murthy et al., 2004), immunomodulatory activity (Gracious Ross et al., 2001; Shabtay et al., 2008), antibacterial activity (Navarro et al., 1996), and antiatherosclerotic and antioxidative capacities (Tzulker et al., 2007). However, fresh pomegranate biomass contains high levels of moisture and soluble sugars (Shabtay et al., 2008), rendering its disposal, drying, or preservation problematic. Moreover, the processing of pomegranate parts is limited to the harvest season of this fruit, from October to December. These limitations complicate preservation and standardization of this active biomass as a continuous and steady supplement to ruminant rations. Therefore, the Israeli company Gan Shmuel Food Ltd. (Kibbutz Gan-Shmuel, Israel) has recently developed an efficient industrial process to produce and standardize a proprietary concentrated pomegranate extract $(\mathbf{C P E})$. This $\mathrm{CPE}$ is made by chopping up the pomegranate parts remaining after pomegranate juice production, including peels, residual arils, and inner parts of the fruit, and subjecting them to water extraction filtering and evaporation procedures, which result in concentration of the active compounds. The final CPE is standardized to ensure a uniform and constant DM content, and is available year round for feeding ruminants.

In a previous study, Shabtay et al. (2008) demonstrated that dietary supplementation with fresh pomegranate peels promoted a significant increase in feed intake, with a positive tendency toward increased BW gain in bull calves. They suggested that the antioxidant and immunomodulatory properties of pomegranate peels might improve immune function, which could benefit calf health. On the other hand, Oliveira et al. (2010) found that feeding a pomegranate extract to young calves for the first $70 \mathrm{~d}$ of life suppressed the intake of grain and the digestibility of fat and protein, likely because of the high tannin content. To the best 
of our knowledge, published information is lacking on the effects of adding CPE to rations on milking performance, in vivo digestibility, and the profile of the rumen bacterial population in high-producing lactating cows. Moreover, considering the discrepancies between the findings of Shabtay et al. (2008) and Oliveira et al. (2010), different pomegranate components appear to have different effects on the intake, digestibility, and milking performance of cows.

It should be noted that although polyphenolic compounds might improve animal health, they can also decrease proteolytic activity and thus compromise protein digestion (Broderick et al., 1991). Therefore, potential benefits of added pomegranate components on cow health and production should be considered relative to the potential decline in nutrient digestion and milk production. This conflict dictates a need to measure optimal dosages of CPE inclusion in the TMR of lactating cows. We assumed, based on preliminary studies assessing milk and milk protein production under different levels of CPE addition (data not shown), that addition of CPE in the range of 1 to $4 \%$ of TMR DM would not interfere with protein digestibility and would still be effective in promoting animal health and milk production.

The objective of this study was to determine the appropriate and effective dose of CPE addition by supplementing it at levels of $0,1,2$, or $4 \%$ to the TMR of 4 groups of 10 individually fed cows. Intake; in vivo digestibility of DM, CP, and NDF; profile of the rumen bacterial population; and milk yield and composition were measured.

\section{MATERIALS AND METHODS}

\section{Cows, Diets, and Sampling Procedures}

Forty Israeli Holstein cows were housed at the Agricultural Research Organization dairy farm in a shaded corral with free access to water, in the autumn of 2010. Cows were divided at the onset of the experiment into 4 feeding groups, with 10 cows each, similar in lactation number (3.3), DIM (145), and daily milk production $(41 \mathrm{~kg} / \mathrm{cow})$. Ten cows in the control group were individually fed a typical Israeli TMR for 6 wk (Tables 1 and 2), whereas the 3 experimental groups were individually fed the same TMR with CPE added on top of the served ration at levels of 1, 2, or $4 \%$ of TMR DM. The CPE composition used in this study was (in $\mathrm{g} /$ $\mathrm{kg}$ of DM) DM (451), punicalagins $\mathrm{A}+\mathrm{B}$ (26.5), and ellagic acid (2.5; all assessed in a Varian HPLC instrument with a 9012 pump and 9050 UV detector; Varian, Palo Alto, CA); total soluble phenolics (63); soluble sugars (288); CP (20.8); and ash (50.2). The $\mathrm{pH}$ of
Table 1. Composition of the basic TMR fed as the control diet

\begin{tabular}{lr}
\hline Ingredient $(\mathrm{g} / \mathrm{kg}$ of $\mathrm{DM})$ & Amount \\
\hline Wheat silage & 100.0 \\
Oat hay & 80.0 \\
Corn silage & 100.0 \\
Clover hay & 23.0 \\
Soybean hulls & 78.0 \\
Soybean meal (solvent-extracted) & 22.0 \\
Ground corn grain & 129.0 \\
Ground barley grain & 87.0 \\
Ground wheat grain & 44.0 \\
Whole cottonseeds & 20.0 \\
Corn gluten feed & 96.0 \\
Corn distillers dried grains & 89.0 \\
Canola meal & 38.0 \\
Whey solids & 36.0 \\
NaHCO & 7.4 \\
NaCl & 6.0 \\
CaCO & 9.0 \\
Ca- CCA $^{1}$ & 14.0 \\
Soy molasses & 17.0 \\
Urea $_{\text {Trace mineral }+ \text { vitamin mixture }}{ }^{2}$ & 4.0 \\
LCalin salts of long-chan & 0.6 \\
\hline
\end{tabular}

${ }^{1}$ Calcium salts of long-chain fatty acids.

${ }^{2}$ Contains (g/kg of DM) Zn, 24; Fe, 24; Cu, 12.8; Mn, 24; I, 1.44; Co, 0.32 ; Se, 0.32 ; and 16,000,000 IU of vitamin A, 3,200,000 IU of vitamin $\mathrm{D}_{3}$, and $48,000 \mathrm{IU}$ of vitamin $\mathrm{E}$.

the CPE was 2.65. Total soluble phenolics (gallic acid equivalents) were assayed by the colorimetric method using the Folin-Ciocalteu reagent (Singleton et al., 1999). The CPE concentrations were determined based on preliminary studies with a smaller number of cows, in which the addition was found not to interfere with milk and milk protein production (J. Miron, unpublished data).

The 4 TMR were fed once daily at $1000 \mathrm{~h}$ with ad libitum intake, allowing for 5 to $10 \%$ orts, and the cows were milked 3 times daily at 0600,1400 , and $2200 \mathrm{~h}$. Cows were fed in individual feeders via a computerized monitoring system designed to identify individual cows electronically and automatically control and record each cow's daily feed intake (Miron et al., 2003; Adin

Table 2. Chemical composition ( \pm SEM) of the basic TMR fed as the control diet

\begin{tabular}{lc}
\hline Component & Amount \\
\hline DM (g/kg of TMR) & $633 \pm 18.9$ \\
CP (g/kg of TMR DM) & $165 \pm 3.3$ \\
Ether extract (g/kg of TMR DM) & $48.7 \pm 0.96$ \\
NDF (g/kg of TMR DM) & $408 \pm 7.1$ \\
Hemicellulose (g/kg of TMR DM) & $208 \pm 4.2$ \\
Cellulose (g/kg of TMR DM) & $145 \pm 9.3$ \\
Lignin (g/kg of TMR DM) & $52.7 \pm 7.03$ \\
Roughage NDF (g/kg of TMR DM) & $180 \pm 7.2$ \\
Ca (g/kg) & $9.0 \pm 0.30$ \\
P (g/kg) & $5.24 \pm 0.090$ \\
In vitro DM digestibility (\%) & $68.6 \pm 1.06$ \\
In vitro NDF digestibility (\%) & $56.6 \pm 0.95$ \\
\hline
\end{tabular}


et al., 2009). Both computerized and manual weighing of feed and orts were performed to monitor the daily feed intake of each cow. The voluntary daily DMI of individual cows was determined based on DM content in TMR sampled daily and in the feed refusals of individual cows. Cow BCS was determined on a weekly basis (Adin et al., 2009).

Automatic meters (Afimilk SAE, Afikim, Israel) recorded the milk yield $(\mathrm{kg})$ of each cow for each milking and calculated daily averages. Milk samples were collected in 3 sequential milkings on a weekly basis throughout the study. Each set of milk samples for each cow was stored at $4^{\circ} \mathrm{C}$ in the presence of a 2-bromo2-nitropropane-1,3-diol tablet until analysis for fat, true protein, and lactose by infrared analysis (Israeli Cattle Breeders Association Laboratory, Caesaria, Israel), using a MilkoScan 4000 instrument (Foss Electric, Hillerød, Denmark). Energy-corrected milk yield was calculated using the following equation (NRC, 2001): ECM $(\mathrm{kg} / \mathrm{d})=$ milk yield $(\mathrm{kg} / \mathrm{d}) \times[(0.3887 \times$ milk fat $\%)+(0.2356 \times$ milk protein - urea $\%)+(0.1653 \times$ milk lactose \%)] $/ 3.1338 \mathrm{MJ} / \mathrm{kg}$.

The animal performance study was carried out according to the guidelines and under the supervision of the Animal Care Committee of the Agricultural Research Organization (Bet-Dagan, Israel).

\section{Chemical and In Vitro Analyses}

Samples of the TMR fed in the experiment, as well as fecal samples, were dried for $48 \mathrm{~h}$ in an aerated $60^{\circ} \mathrm{C}$ oven, ground to pass a 1-mm screen, and analyzed according to the methods of AOAC (1990) for DM (method 925.40), total N (method 984.13), ether extract (method 920.39), and ash (method 923.03). Crude protein was calculated as $\mathrm{N} \times 6.25$.

Neutral detergent fiber was assayed with heat-stable amylase without sodium sulfite and expressed exclusive of residual ash (Van Soest et al., 1991). Acid detergent fiber was determined using the sequential method on amylase-treated NDF residue and expressed exclusive of residual ash (Van Soest et al., 1991). Hemicellulose was calculated as NDF minus ADF. Lignin solubilized with sulfuric acid [lignin (sa)] was assayed as the residual OM remaining after hydrolysis of ADF with $72 \%$ sulfuric acid. Cellulose was calculated as ADF minus lignin (sa). An Ankom apparatus (Ankom 220 , Ankom Technology, Macedon, NY) was used to extract and filter amylase-treated NDF, ADF, and lignin (sa). In vitro DM digestibility of the TMR was determined according to the 2-stage technique of Tilley and Terry (1963).

\section{In Vivo Digestibility Measurements}

At wk 5 of the experiment, $4 \mathrm{~d}$ were assigned for daily sampling of TMR, feed refusals, and feces from the 10 cows involved in each of the 4 treatments. Estimation of daily fecal excretion was based on indigestible NDF concentrations in feces and the TMR. Samples of the TMR were composited on a daily basis, dried $\left(60^{\circ} \mathrm{C}\right.$ for $48 \mathrm{~h}$ ), and ground through a 1.0-mm sieve (Retsch S-M-100, Retsch, Haan, Germany). Fecal grab samples were collected 3 times daily for $4 \mathrm{~d}$, at 8 -h intervals, with each day $2.5 \mathrm{~h}$ later than the preceding day. Fecal samples were composited (on a DM basis) from each cow during the collection period, dried at $60^{\circ} \mathrm{C}$ for $48 \mathrm{~h}$ in a forced-air oven, ground to pass through a 1.0-mm screen, and then used for chemical analyses as described above and for indigestible NDF content determination in the TMR and fecal pooled samples. The 2-stage in vitro digestibility technique of Tilley and Terry (1963) was used to analyze the indigestible NDF content (after incubation with rumen fluid for $72 \mathrm{~h}$ ) of TMR and fecal pooled samples from each cow, for in vivo digestibility calculation according to the methods described by Lippke et al. (1986) and Adin et al. (2009). The indigestible NDF was used as an internal marker for the apparent total tract DM digestibility analysis. The in vivo digestibility of each chemical component (i.e., DM, $\mathrm{CP}$, NDF, cellulose, and hemicellulose) was calculated in each cow using the average individual DMI and fecal output.

\section{Rumen pH Measurement}

Once a week, 500-mL rumen fluid samples free of saliva were collected with a rumen vacuum sampler from each cow $1 \mathrm{~h}$ before feeding $(0900 \mathrm{~h})$ and $3 \mathrm{~h}$ after feeding $(1300 \mathrm{~h})$. The $\mathrm{pH}$ values were immediately determined by a portable $\mathrm{pH}$ meter.

\section{Pattern of Rumination}

All cows were equipped with rumination tag monitoring systems that measured the duration of daily rumination $(\mathrm{min} / \mathrm{d})$ over the 6 wk of the experiment. Commercial tags (Hi-Tag TM, SCR Engineers, Netanya, Israel; htpp://www.scr.co.il) that are routinely used in Israeli herds were used for this purpose. The rumination data were automatically downloaded after each milking, stored in the herd computer, and analyzed by special software. The basic principle of rumination time measurement consisted of analyzing the isolated chewing sounds during rumination, excluding the sounds related to eating. 


\section{Bacterial Isolation}

Isolation of the rumen microbial populations, including fiber-adherent and free-floating bacteria, was performed as described by Stevenson and Weimer (2007). Rumen fluid was sampled from 16 cows before the start of the CPE addition experiment and during the wk 5 of the experiment in 5 cows given $1 \%$ CPE, 6 cows given $2 \% \mathrm{CPE}$, and 5 cows given $4 \% \mathrm{CPE}$. Rumen fluid from each cow was homogenized in a blender for $2 \mathrm{~min}$, the homogenate was centrifuged at $10,000 \times g$ for 30 min at $4^{\circ} \mathrm{C}$, and the pellet was dissolved in extraction buffer (100 m $M$ Tris-HCl, $10 \mathrm{~m} M$ EDTA, $0.15 \mathrm{M} \mathrm{NaCl}$; $\mathrm{pH}$ 8.0); the 1-g pellet was dissolved in $4 \mathrm{~mL}$ of buffer and incubated at $4^{\circ} \mathrm{C}$ for $1 \mathrm{~h}$ because chilling has been shown to maximize the release of particle-associated bacteria from ruminal contents. The suspension was then centrifuged gently at $500 \times g$ for $15 \mathrm{~min}$ at $4^{\circ} \mathrm{C}$ to remove ruptured plant particles while keeping the bacterial cells in suspension. The supernatant was then passed through 4 layers of cheesecloth and centrifuged $\left(10,000 \times g, 25 \mathrm{~min}, 4^{\circ} \mathrm{C}\right)$, and the microbial pellets were kept at $-20^{\circ} \mathrm{C}$ until DNA extraction.

\section{DNA Extraction}

The DNA extraction was performed as described by Stevenson and Weimer (2007). Cell lysis was achieved by bead disruption with phenol followed by phenol/ chloroform DNA extraction. The final supernatant was precipitated with 0.6 vol of isopropanol, resuspended overnight in 50 to $100 \mu \mathrm{L}$ of TE buffer $(100 \mathrm{~m} M$ Tris $\mathrm{pH} 8,1 \mathrm{~m} M$ EDTA), and then stored at $4^{\circ} \mathrm{C}$ for shortterm use, or archived at $-80^{\circ} \mathrm{C}$.

\section{Automated Ribosomal Intergenic Spacer Analysis}

This method uses the natural variation in length in the $16 \mathrm{~S}$ and $23 \mathrm{~S}$ rRNA occurring between different bacterial taxa to generate a whole bacterial community fingerprint, which can be further analyzed by statistical evaluation of the changes before and after CPE addition to the ration. The DNA from all rumen samples was subjected to PCR amplification for automated ribosomal intergenic spacer analysis (ARISA; Fisher and Triplett, 1999). The oligonucleotide primers ITSF (5'-GTCGTAACAAGGTAGCCGTA-3') and ITSRtet (5'-GCCAAGGCATCCAAC-3') were as described recently by Welkie et al. (2010) for ARISA of rumen bacteria, with the fluorescent molecule being TET. The ARISA PCR were carried out in a $15-\mu \mathrm{L}$ vol containing Fermentas Dreamtaq (Madison, WI) master mix, $0.5 \mu \mathrm{L}$ of $10 \mu \mathrm{M}$ stock solution for each primer, $20 \mathrm{ng}$ of template DNA, and $4.5 \mu \mathrm{L}$ of nuclease-free water.
Polymerase chain reactions were carried out using a Sensiquest thermocycler (Sensiquest, Gottingen, Germany) under the following conditions: $94^{\circ} \mathrm{C}$ for $2 \mathrm{~min}$ (1 cycle), followed by 30 cycles of $94^{\circ} \mathrm{C}$ for $1 \mathrm{~min}, 55^{\circ} \mathrm{C}$ for $60 \mathrm{~s}$, and $72^{\circ} \mathrm{C}$ for $120 \mathrm{~s}$, and finally 1 cycle of $72^{\circ} \mathrm{C}$ for $5 \mathrm{~min}$.

\section{ARISA Resolution and Analysis}

For each DNA sample, 2 technical replicates of PCR products were analyzed using an ABI Prism 3100 Genetic Analyzer (Applied Biosystems, Carlsbad, CA). The labeled fragments were separated on the capillary sequencer along with a custom-made ROX-labeled 250- to 1,150-bp standard (BioVentures, Murfreesboro, $\mathrm{TN}$ ). Raw data generated by the genetic analyzer were initially analyzed using GeneMarker software (SoftGenetics, State College, PA) according to the method of Kovacs et al. (2010) and Jami and Mizrahi (2012b). After performing accurate size calling using the program, all data were exported to Microsoft Excel (Microsoft Corporation, Redmond, WA) for further analysis. All operational taxonomic units (OTU) with a fluorescence intensity of 10 relative fluorescence units or less were excluded. The remaining OTU were binned as described by Brown et al. (2005) with the following parameters: bins of $3 \mathrm{bp}( \pm 1 \mathrm{bp})$ for fragments up to $700 \mathrm{bp}$ in length, bins of $5 \mathrm{bp}$ for fragments between 700 and 1,000 bp in length, and bins of $10 \mathrm{bp}$ for fragments more than 1,000 bp in length. Intensities were then summed for each bin. Next, relative intensities for each binned OTU in a given sample were calculated and OTU that constituted less than $0.1 \%$ of the total intensity of the sample were excluded. Technical duplicates were compared as if they were individual samples and served as an internal control for the quality of the analysis. Duplicates that were not similar to each other were further checked for technical run problems and were either discarded or run again. The file generated by Excel was transferred to PAleontological STatistics (PAST) software (Hammer et al., 2001; http://www.nhm.uio.no/norges/past/download.html). Bray-Curtis distance index calculations, as well as nonmetric multidimensional plotting, were performed using this program. The data were further processed using a Microsoft Excel program.

\section{Real-Time PCR}

Quantitative real-time PCR analysis was performed to investigate the relative abundance of 12 bacterial species through amplification of their copy of the $16 \mathrm{~S}$ rRNA gene using the primers shown in Table 3 (Walter et al., 2000; Stevenson and Weimer, 2007; Zhou et 
Table 3. Polymerase chain reaction primers used for detection of rumen bacterial species in this study using real-time PCR

\begin{tabular}{|c|c|c|}
\hline Bacterium & Primer $\left(5^{\prime} \rightarrow 3^{\prime}\right)$ & Reference \\
\hline \multirow[t]{2}{*}{ Butyrivibrio fibrisolvens $\mathrm{H} 1 \mathrm{Cc}$} & ACCGCATAAGCGCACGGA & Stevenson and Weimer (2007) \\
\hline & CGGGTCCATCTTGTACCGATAAAT & Stevenson and Weimer (2007) \\
\hline Eubacterium ruminantium GA195 & CTCCCGAGACTGAGGAAGCTTG & Stevenson and Weimer (2007) \\
\hline \multirow[t]{2}{*}{ Fibrobacter succinogenes S85 } & GCGGGTAGCAAACAGGATTAGA & Stevenson and Weimer (2007) \\
\hline & CCCCCGGACACCCAGTAT & Stevenson and Weimer (2007) \\
\hline Megasphaera elsdenii T81 & AGATGGGGACAACAGCTGGA & Stevenson and Weimer (2007) \\
\hline \multirow[t]{2}{*}{ Prevotella bryantii $B 14$} & AGCGCAGGCCGTTTGG & Stevenson and Weimer (2007) \\
\hline & GCTTCCTGTGCACTCAAGTCTGAC & Stevenson and Weimer (2007) \\
\hline \multirow{2}{*}{ Prevotella ruminicola 23} & GAAAGTCGGATTAATGCTCTATGTTG & Stevenson and Weimer (2007) \\
\hline & CATCCTATAGCGGTAAACCTTTGG & Stevenson and Weimer (2007) \\
\hline \multirow[t]{2}{*}{ Ruminococcus albus 7} & TGTTAACAGAGGGAAGCAAAGCA & Stevenson and Weimer (2007) \\
\hline & TGCAGCCTACAATCCGAACTAA & Stevenson and Weimer (2007) \\
\hline Streptococcus bovis JB1 & ATGATGGCAACTAACAATAGGGGT & Stevenson and Weimer (2007) \\
\hline \multirow[t]{2}{*}{ Succinivibrio dextrinosolvens 226} & CGTCAGCTCGTGTCGTGAGA & Stevenson and Weimer (2007) \\
\hline & CCCGCTGGCAACAAAGG & Stevenson and Weimer (2007) \\
\hline \multirow[t]{2}{*}{ Domain bacteria } & ACTCCTACGGGAGGCAGCAGT & Walter et al. (2000) \\
\hline & GTATTACCGCGGCTGCTGGCAC & Walter et al. (2000) \\
\hline \multirow[t]{2}{*}{ Total methanogens } & CCG GAG ATG GAA CCT GAG AC & Zhou et al. (2009) \\
\hline & CGG TCT TGC CCA GCT CTT ATT C & Zhou et al. (2009) \\
\hline
\end{tabular}

al., 2009). A standard curve was generated for each bacterial strain selected. By amplifying a serial 2-fold dilution of gel-extracted PCR products obtained by the amplification of each amplicon, individual standard curves were generated suitable for the quantification of each bacterial strain individually. A standard curve was also generated for the total bacterial $16 \mathrm{~S}$ rRNA gene in the samples by amplifying 10-fold dilutions of the gel-purified PCR product of 1 rumen sample. The standard curves were obtained using 4 dilution points, and were calculated using Rotorgene 6000 series software (Qiagen, Hilden, Germany). Subsequent quantifications were calculated with the same program using the standard curve generated in each run (equating to 1 bacterial species), and at least 1 known purified product dilution used for the standard curves was added to each quantification reaction to assess the reproducibility of the reactions. All standard curves obtained met the required standards of efficiency $\left(\mathrm{R}^{2}>0.99,90 \%>\mathrm{E}>\right.$ $115 \%$ ). Real-time PCR was performed in a $10-\mu \mathrm{L}$ reaction mixture containing $5 \mu \mathrm{L}$ of Absolute Blue SYBR Green Master Mix (Thermo Scientific, Waltham, MA), $0.5 \mu \mathrm{L}$ of each primer $(10 \mu M$ working concentration $), 3$ $\mu \mathrm{L}$ of nuclease-free water, and $2 \mu \mathrm{L}$ of $10-\mathrm{ng}$ DNA template. Amplification consisted of 1 hold cycle at $95^{\circ} \mathrm{C}$ for $15 \mathrm{~min}$ for initial denaturation and activation of the hot-start polymerase system, and then 40 cycles at $95^{\circ} \mathrm{C}$ for $10 \mathrm{~s}$, followed by annealing at $60^{\circ} \mathrm{C}$ for $15 \mathrm{~s}$ and extension at $72^{\circ} \mathrm{C}$ for $20 \mathrm{~s}$. To determine the specificity of amplification, a melting curve of PCR products was monitored by slow heating in increments of $1^{\circ} \mathrm{C}$ and holding for $10 \mathrm{~s}$ from 60 to $99^{\circ} \mathrm{C}$, with fluorescence collection at $1^{\circ} \mathrm{C}$ intervals. Quantification of the selected bacteria was performed by dividing the number of the specific bacterial count obtained for each bacterium, using the appropriate set of primers, by the total bacterial count obtained by amplification of the universal bacterial primers.

\section{Statistical Analyses}

Comparisons among the 4 groups of 10 cows, each fed the 4 dietary treatments, with respect to individual DMI, rumen $\mathrm{pH}$, duration of rumination, BCS, milk and ECM yield, and milk composition were performed with the repeated-measurement PROC MIXED model of SAS (SAS Institute, 1996), and data are reported in Tables 4 and 5 as the daily means for the $42 \mathrm{~d}$ of the experiment. Tukey's test (SAS Institute, 1996) was used for comparisons among means. A community comparison and statistical analysis were performed using the PAST software (http://www.nhm.uio.no/norges/ past/download.html). The Bray-Curtis distance index was calculated, and the rarefaction test was performed using this program. Data were further processed using Microsoft Excel. 
Table 4. Average intake and in vivo digestibility data of midlactating cows individually fed TMR with different levels of concentrated pomegranate extract $(\mathrm{CPE})$ additive

\begin{tabular}{|c|c|c|c|c|c|c|c|}
\hline \multirow[b]{2}{*}{ Parameter } & \multicolumn{4}{|c|}{ Diet } & \multirow[b]{2}{*}{ SEM } & \multicolumn{2}{|c|}{$P$-value } \\
\hline & Control & $1 \% \mathrm{CPE}$ & $2 \% \mathrm{CPE}$ & $4 \% \mathrm{CPE}$ & & Linear & Quadratic \\
\hline DMI $(\mathrm{kg} / \mathrm{d})$ & $28.3^{\mathrm{b}}$ & $29.4^{\mathrm{a}}$ & $28.6^{\mathrm{b}}$ & $29.7^{\mathrm{a}}$ & 0.11 & 0.53 & 0.014 \\
\hline DM digestibility (\%) & $57.8^{\mathrm{b}}$ & $56.6^{\mathrm{b}}$ & $58.2^{\mathrm{b}}$ & $60.9^{\mathrm{a}}$ & 0.53 & 0.62 & 0.007 \\
\hline $\mathrm{CP}$ intake $(\mathrm{kg} / \mathrm{d})$ & $4.67^{\mathrm{b}}$ & $4.85^{\mathrm{a}}$ & $4.72^{\mathrm{b}}$ & $4.90^{\mathrm{a}}$ & 0.02 & 0.53 & 0.014 \\
\hline CP digestibility (\%) & $60.5^{\mathrm{b}}$ & $60.1^{\mathrm{b}}$ & $60.6^{\mathrm{b}}$ & $64.8^{\mathrm{a}}$ & 0.49 & 0.013 & 0.016 \\
\hline NDF intake $(\mathrm{kg} / \mathrm{d})$ & $11.5^{\mathrm{b}}$ & $12.0^{\mathrm{a}}$ & $11.7^{\mathrm{b}}$ & $12.1^{\mathrm{a}}$ & 0.05 & 0.53 & 0.014 \\
\hline Cellulose digestibility (\%) & $46.2^{\mathrm{ab}}$ & $44.9^{\mathrm{b}}$ & $44.5^{\mathrm{b}}$ & $48.6^{\mathrm{a}}$ & 0.77 & 0.2 & 0.27 \\
\hline Hemicellulose intake ( $\mathrm{kg} / \mathrm{d}$ ) & $5.89^{\mathrm{b}}$ & $6.12^{\mathrm{a}}$ & $5.95^{\mathrm{b}}$ & $6.18^{\mathrm{a}}$ & 0.02 & 0.53 & 0.014 \\
\hline Hemicellulose digestibility (\%) & $43.9^{\mathrm{b}}$ & $40.3^{c}$ & $40.8^{\mathrm{c}}$ & $46.3^{\mathrm{a}}$ & 0.79 & 0.13 & 0.018 \\
\hline Rumination time $(\mathrm{h} / \mathrm{d})$ & $7.52^{\mathrm{b}}$ & $7.58^{\mathrm{b}}$ & $7.63^{\mathrm{b}}$ & $8.14^{\mathrm{a}}$ & 0.05 & 0.44 & 0.018 \\
\hline Rumen pH & $6.16^{\mathrm{b}}$ & $6.52^{\mathrm{a}}$ & $6.68^{\mathrm{a}}$ & $6.43^{\mathrm{a}}$ & 0.06 & 0.58 & 0.05 \\
\hline
\end{tabular}

${ }^{\mathrm{a}-\mathrm{c}}$ Means within a row with different superscripts differ $(P<0.05)$ using a $t$-test for pairwise comparison.

\section{RESULTS}

\section{Intake, Digestibility, and Performance}

Ingredients and chemical composition of the basic TMR fed to cows individually with various levels of added CPE are given in Tables 1 and 2, respectively. Effects of the CPE addition were reflected by 3.9 and $4.9 \%$ increases in voluntary DMI $(P<0.05)$ in the $1 \%$ CPE and $4 \%$ CPE groups, respectively, compared with control cows (Table 4). The higher intake of cows fed $\mathrm{CPE}$ was accompanied by higher ruminal $\mathrm{pH}$ compared with the control cows. Cows fed the $4 \%$ CPE supplement showed longer daily rumination times compared with cows in the other treatment groups (Table 4), along with higher DM, CP, NDF, cellulose, and hemicellulose digestibility (Table 4).

The improvement in intake, digestibility, and ruminal $\mathrm{pH}$ (Table 5) of cows fed the 4\% CPE compared with control cows was accompanied by an $8.2 \%$ increase in average milk production (Table 5; $P<0.05$ ). Milk fat content was greater in the control cows than in the groups fed CPE, but milk protein content of the cows fed 2 and $4 \% \mathrm{CPE}$ was higher than that of the control group. This was reflected in a higher average ECM yield in cows fed the 2 and $4 \% \mathrm{CPE}$ compared with control cows. The efficiency of ECM production ( $\mathrm{kg}$ of ECM yield $/ \mathrm{kg}$ of DMI) and BCS change were not affected by 2 and $4 \%$ CPE addition to the TMR (Table 5).

\section{Whole Bacterial Community Analysis}

Whole community analysis was performed using ARISA to compare the animals of each group before and after the CPE supplementation period. This analysis revealed that as the relative quantity of $\mathrm{CPE}$ in the feed of the animals increased, the more it influenced the microbial community, with the addition of $1 \% \mathrm{CPE}$ showing no change in the community $(R=0.28$ and not significant). The 2 other groups showed significant, dose-dependent changes in the bacterial community. The $2 \%$ CPE group had an $R$-value of 0.5 , and the $4 \%$ CPE group had an $R$-value of 0.67 , with significant differences before and after the treatment for both groups $(P<0.01 ;$ Figure 1).

Table 5. Performance data of midlactation cows individually fed TMR with different levels of concentrated pomegranate extract (CPE) additive

\begin{tabular}{|c|c|c|c|c|c|c|c|}
\hline Parameter & \multicolumn{4}{|c|}{ Diet } & SEM & \multicolumn{2}{|c|}{$P$-value } \\
\hline Average milk yield $(\mathrm{kg} / \mathrm{d})$ & $41.5^{\mathrm{d}}$ & $43.8^{\mathrm{b}}$ & $42.6^{\mathrm{c}}$ & $45.1^{\mathrm{a}}$ & 0.22 & 0.30 & 0.05 \\
\hline Average milk protein $(\%)$ & $2.95^{\mathrm{a}}$ & $2.95^{\mathrm{a}}$ & $3.04^{\mathrm{b}}$ & $3.03^{\mathrm{b}}$ & 0.01 & 0.5 & 0.04 \\
\hline Average milk protein yield $(\mathrm{kg} / \mathrm{d})$ & $1.22^{\mathrm{a}}$ & $1.29^{\mathrm{abc}}$ & $1.25^{\mathrm{ab}}$ & $1.39^{\mathrm{c}}$ & 0.02 & 0.24 & 0.04 \\
\hline Average milk fat yield $(\mathrm{kg} / \mathrm{d})$ & $1.39^{\mathrm{a}}$ & $1.27^{\mathrm{a}}$ & $1.32^{\mathrm{a}}$ & $1.37^{\mathrm{a}}$ & 0.03 & 0.78 & 0.6 \\
\hline BCS change (units) & 0.05 & 0.03 & 0.09 & 0.04 & 0.026 & 0.97 & 0.81 \\
\hline
\end{tabular}

\footnotetext{
${ }^{\mathrm{a}-\mathrm{d}}$ Means within a row with different superscripts differ $(P<0.05)$ using a $t$-test for pairwise comparison.
} 


\section{Bacterial and Archaeal Composition Analysis}

Six of the 12 bacterial species quantified showed significantly different abundance $(P<0.05)$ before and after CPE addition (Figure 2). An increase in abundance was seen in bacterial species related to soluble sugar and lactic acid metabolism, such as a 2-fold increase in Eubacterium ruminantium GA195 and Streptococcus bovis JB1, and between 10- and 20-fold increases in Succinivibrio dextrinosolvens 22b. A decrease in abundance was observed in 2 of the 3 main cellulolytic bacterial species, with a decrease of between 20- and 30-fold in Fibrobacter succinogenes $S 85$ depending on the amount of CPE supplementation. A smaller 2-fold decrease was observed in Ruminococcus albus \%. A slight 2-fold increase was observed in the abundance of Ruminococcus flavefaciens $F D-1$, but this change was significant only in the $2 \%$ CPE group. For the composition of the methanogenic archaea community, a significant increase in abundance after CPE supplementation was observed for the groups fed 2 and $4 \%$ CPE supplement, but not in the group fed 1\% CPE (Figure 3).

\section{DISCUSSION}

\section{Effects of CPE Tannins on Intake, Digestibility, and Performance}

Pomegranate peel is rich in tannins, which were previously shown to have both adverse and beneficial effects in ruminants (Makkar, 2003). Moderate concentrations of condensed tannins (2 to $4 \%$ of DM) in the diet of sheep improve production efficiency in ruminants without increasing feed intake, as manifested by increases in wool growth, BW gain, milk yield, and ovulation rate (Aerts et al., 1999). Hydrolyzable tannins have been shown to correlate positively with antioxidant activity in pomegranate peel and juice (Gil et al., 2000; Tzulker et al., 2007). In pomegranate, the hydrolyzable tannins include punicalin, ellagic acid, gallagic acid, and punicalagin, which account for $50 \%$ of the antioxidant capacity of pomegranate juice (Gil et al., 2000). Punicalagin was the most abundant tannic component in the CPE $(26.5 \mathrm{~g} / \mathrm{kg})$ used in this study. Among the tannins, punicalagin has the highest lipid peroxidationinhibitory and radical-scavenging activities (Kulkarni et al., 2004), and its beneficial attributes may be of great relevance to cattle health.

On the other hand, high concentrations of hydrolyzable tannins might reduce feed intake, the digestibility of proteins and carbohydrates, and animal performance through their negative effects on palatability and digestion (Broderick et al., 1991; Reed, 1995). In the present study, 1 to $4 \%$ CPE addition increased DMI while improving DM, CP, and NDF intake and digestibility in cows fed the $4 \% \mathrm{CPE}$ supplement (Table 4). The improvement in NDF intake and digestibility might be the result of the added nutritive value of the pomegranate peel itself. These findings suggest the absence of any large negative effects of tannins on palatability or in vivo digestibility, as also reflected in the higher milk and ECM yields of cows fed CPE. However, despite the higher nutrient digestibility in cows fed the $4 \% \mathrm{CPE}$ supplement, their feed utilization efficiency for ECM production was similar to that of control cows. This finding might be related to changes in the bacterial population, in particular the increase in the methaneproducing population (Figure 3), which might interfere with energy utilization for milk production (Zhou et al., 2009). Similar positive effects of pomegranate peel addition on increased palatability and DMI were observed in calves at 11 mo of age fed fresh pomegranate peels in addition to a standard TMR during an 8-wk experiment. Peel intake increased linearly during the feeding experiment without any adverse effect on ADG (Shabtay et al., 2008). The findings of this study suggest that at application levels of up to $4 \% \mathrm{CPE}$, the hydrolyzable tannins originating from the CPE did not interact with dietary proteins, as also suggested by Broderick et al. (1991). However, the increased milk protein yield in the $4 \% \mathrm{CPE}$ group compared with the control group (Table 4) may suggest greater ruminal escape of dietary protein. Thus, the tannins might indeed reduce ruminal digestion of the dietary protein, whereas the improved total tract digestion suggests they did not impair intestinal digestion of dietary protein. This increase in protein digestibility and milk protein yield may be responsible in part for the beneficial effect of $\mathrm{CPE}$ addition through increases in protein supply to the cows.

\section{Effects of CPE on the Rumen Bacterial and Archaeal Community}

This study showed that CPE supplementation affects the composition of the overall ruminal bacteria, as reflected by the ARISA and analysis of similarity results (Figure 1). Nevertheless, this effect did not influence all microorganisms in the same manner (Figures 2 and 3), with some increasing and others decreasing in abundance. A significant effect of CPE on the whole bacterial community was observed at concentrations of 2 and $4 \%$, whereas at a concentration of $1 \% \mathrm{CPE}$, a global effect was not observed (Figures 1, 2, and 3). It appears that CPE supplementation at concentrations of 2 and $4 \%$ significantly increased the abundance of methanogenic archaea (Figure 3). This increase in methanogenic archaea occurred despite the reported 
inhibiting effect of polyphenolic compounds on these species (Patra and Saxena, 2010). This might suggest that the effective portion of polyphenolic compounds within the CPE was not sufficient to inhibit methanogenic archaea. Only the higher concentrations of CPE used in this study affected the bacterial and archaeal communities, suggesting that $\mathrm{CPE}$ addition makes the dominant contribution to that effect. Nevertheless, one cannot exclude the effect of time and its associated changes on the results.

When specific bacteria were examined by quantitative real-time PCR, a differential effect of CPE supplementation was observed with respect to the different bacteria. Some of the examined bacteria did not exhibit any significant change (e.g., Prevotella species), whereas some of the species showed marked changes. The species that exhibited a large increase are involved in soluble sugar utilization, such as $S$. dextrinosolvens, E. ruminantium, and $S$. bovis. The latter species is usually mentioned in the context of starch utilization, but it is also known to utilize soluble sugars (Dehority, 2003). Part of this effect could be due to the enriched soluble sugar composition of the CPE, which would explain the increase in soluble-sugar-utilizing species as well as the increase in methanogenic archaea because these fermentation products might increase $\mathrm{H}_{2}$ availability for methanogenesis. On the other hand, a significant decrease was found with $\mathrm{CPE}$ supplementation in the abundance of 2 of the main known cellulose degraders, F. succinogenes and R. albus. The most dramatic decrease was observed for $F$. succinogenes, which decreased by more than 20 -fold in all samples treated with CPE, regardless of its concentration (Figure 2). The negative effect of CPE on F. succinogenes could be the result of chemical compounds in the $\mathrm{CPE}$, such as polyphenolic compounds, that have antibacterial activity and may have a differential effect on the different rumen bacteria (Chirumbolo, 2011). However, cellulose digestibility did not decrease in the cows fed CPE, and NDF digestibility even increased in the cows fed $4 \%$ CPE (Table 4). This discrepancy might be associated with the finding that cultured bacteria represent only a small fraction of the overall bacterial species in the rumen (Stevenson and Weimer, 2007; Jami and Mizrahi, 2012a). Thus, the existence of other uncultured cellulolytic bacteria that could potentially occupy this niche when the abundance of $F$. succinogenes decreased might explain the lack of decrease in overall cellulose and NDF degradation. The fact that $R$. flavefaciens exhibited a slight increase in abundance in the treated samples might support this assumption, and it might also hold true for other uncharacterized cellulolytic bacteria.
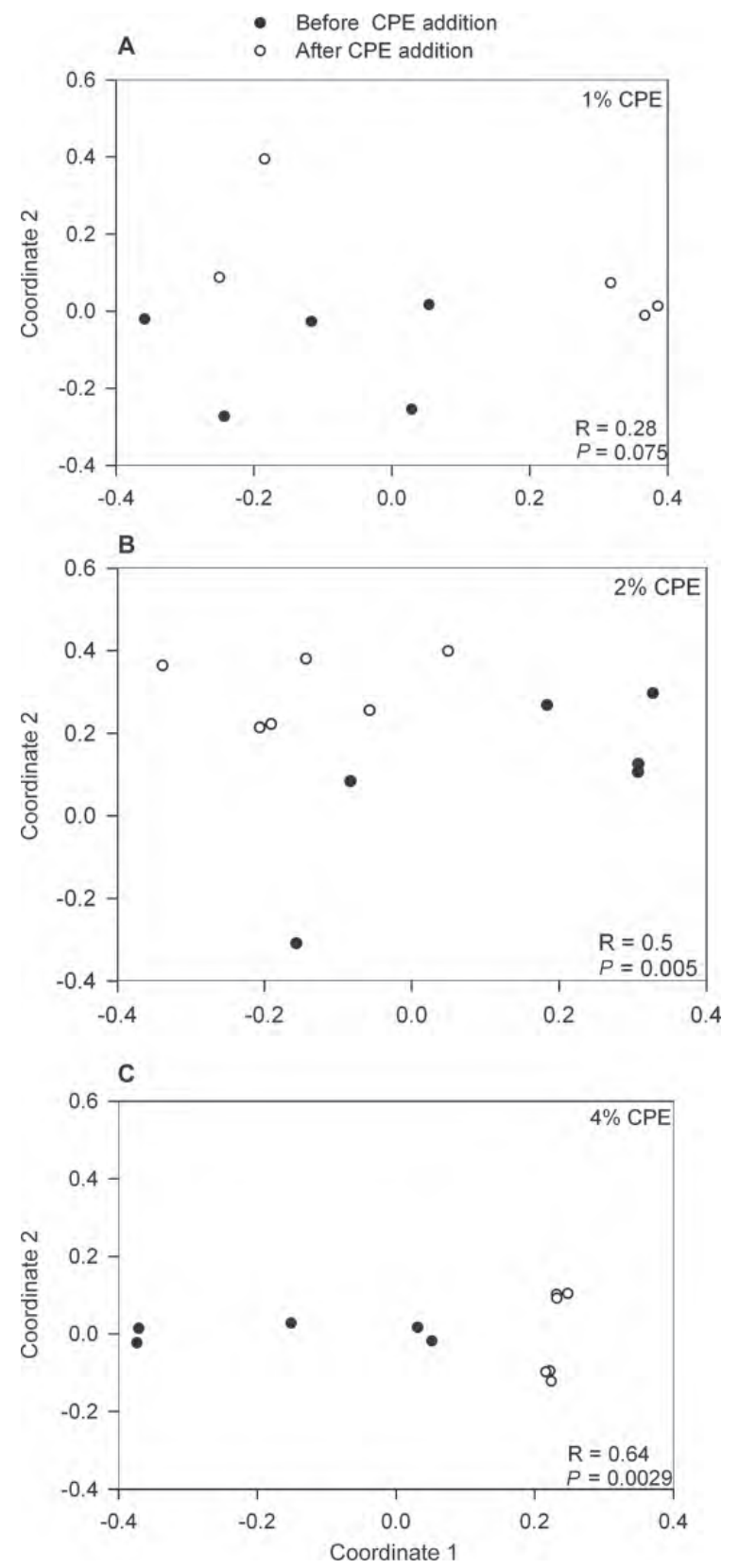

Figure 1. Automated ribosomal intergenic spacer analysis similarity distance of the bacterial communities before and after addition of concentrated pomegranate extract $(\mathrm{CPE})$ to the feed. Distance between the samples was based on the similarity in operational taxonomic unit (OTU) composition of each sample calculated by the BrayCurtis similarity index and plotted using nonmetric multidimensional scaling. Each point represents different samples plotted on a 2-dimensional graph according to their OTU composition and abundance. A greater distance between 2 points implies a lower similarity between them, whereas samples with a more similar bacterial composition and abundance are clustered closer together. Each graph represents the influence of a different concentration of $\mathrm{CPE}$ added to the diet of the animals (noted in the upper right corner of the graph); white dots represent the group before CPE supplementation, and black dots represent the same animals after $30 \mathrm{~d}$ of CPE supplementation. Analyses of similarity $R$-values are displayed in the lower right corner of the graph for each concentration of CPE, with the 2 and $4 \%$ groups, but not the $1 \%$ group, being statistically significant $(P<0.01)$. 

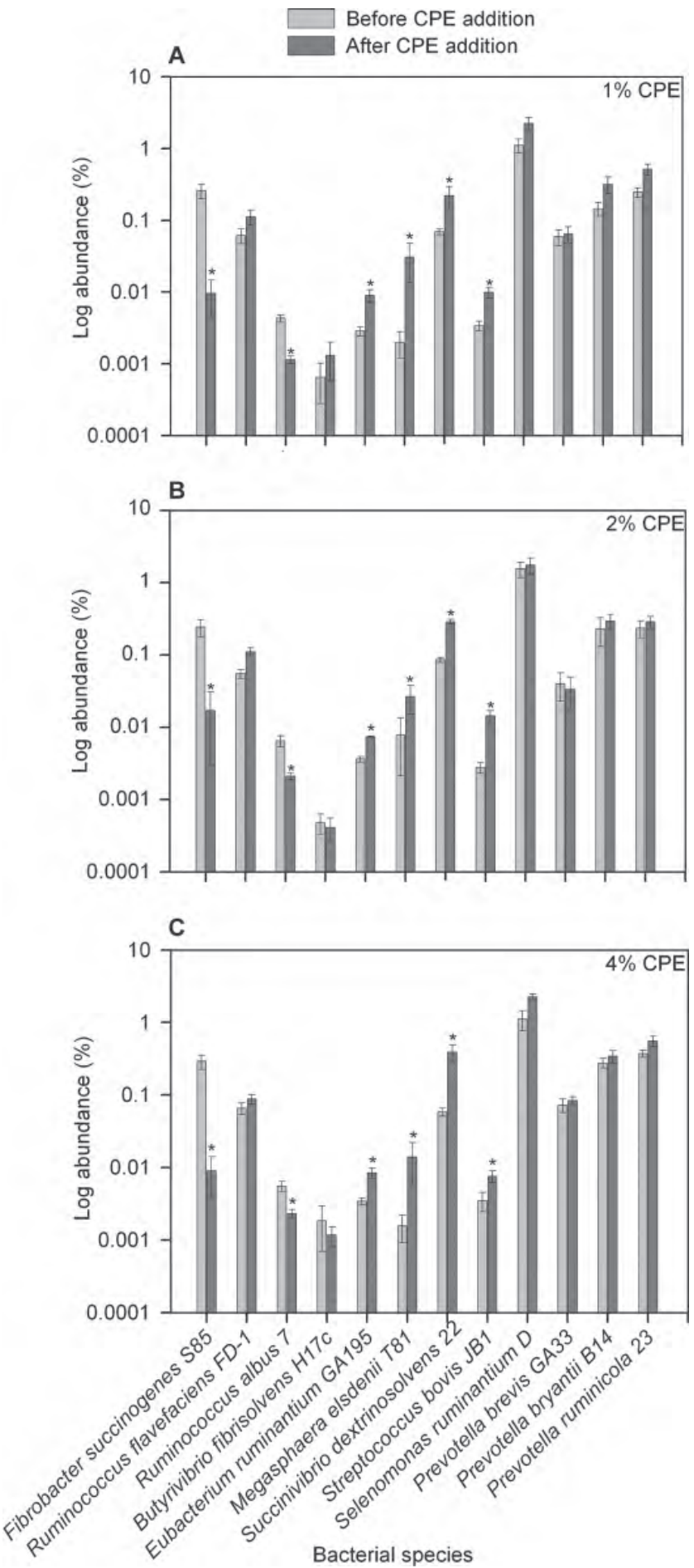

Figure 2. Quantification of known functional bacterial species in the samples using real-time PCR. Each graph displays the log abundance of the selected bacterial species before (light gray bars) and after (dark gray bars) addition of different concentrations of concentrated pomegranate extract (CPE) in the diet of the animals. The $y$-axis denotes the $\log$ abundance of the species quantified and the $x$-axis denotes the bacterial species quantified. The whiskers represent SEM, and asterisks $(*)$ denote significant differences between the ratio observed before and after CPE supplementation for each group $(P<$ $0.05)$.

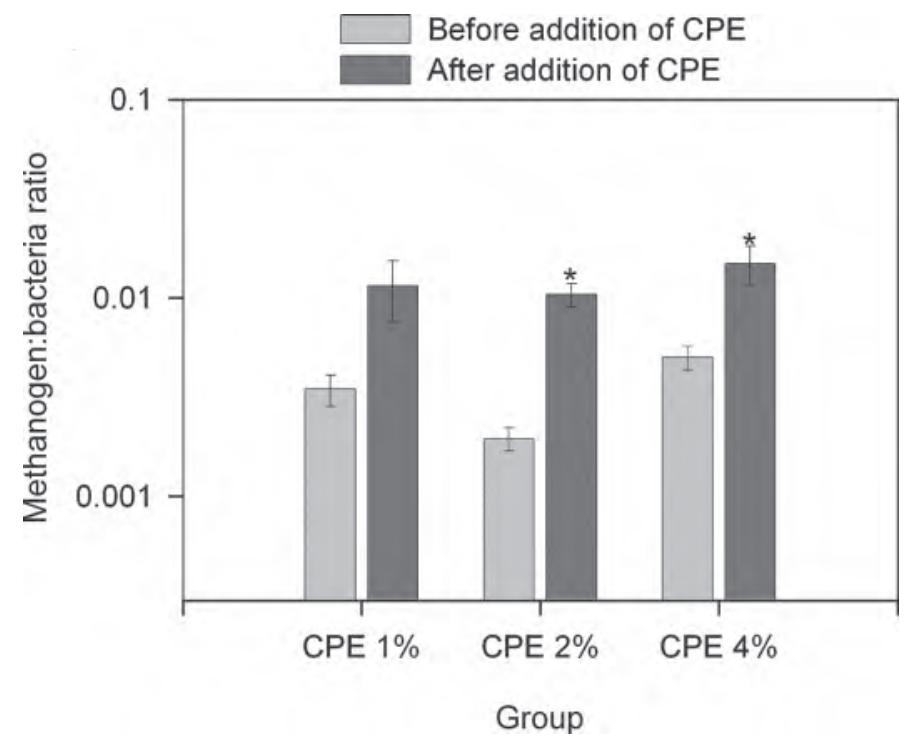

Figure 3. Methanogen:bacteria ratio. Average ratio between the total number of methanogens and the total number of bacteria in samples for each group receiving different concentrations of concentrated pomegranate extract (CPE) supplement. The light gray bars represent the ratio before the addition of $\mathrm{CPE}$, and the dark gray bars represent the ratio after it. Whiskers represent SEM, and asterisks $(*)$ denote significant differences between the ratio observed before and after CPE supplementation for each group $(P<0.05)$.

\section{CONCLUSIONS}

Supplementation of 2 and $4 \%$ CPE had a significant effect on the bacterial and archaeal communities within the rumen, which was also accompanied by beneficial effects on rumen $\mathrm{pH}$ and rumination. In cows fed $4 \%$ $\mathrm{CPE}$, the digestibility of DM, CP, NDF, cellulose, and hemicellulose was increased. In parallel, CPE supplementation increased the DMI of cows and elevated their milk and ECM yields. The connection between these findings and the mechanism by which the effect of $\mathrm{CPE}$ is carried out has yet to be determined.

\section{ACKNOWLEDGMENTS}

This study was supported by the Israel Dairy Board Foundation (Yehud, Israel) Project No. 362-0296.

\section{REFERENCES}

Adin, G., R. Solomon, M. Nikbachat, A. Zenou, E. Yosef, A. Brosh, A Shabtay, S. J. Mabjeesh, I. Halachmi, and J. Miron. 2009. Effect of feeding cows in early lactation with diets differing in roughageneutral detergent fiber content on intake behavior, rumination, and milk production. J. Dairy Sci. 92:3364-3373.

Aerts, R. J., T. N. Barry, and W. C. McNabb. 1999. Polyphenols and agriculture: Beneficial effects of proanthocyanidins in forages. Agric. Ecosyst. Environ. 75:1-12.

AOAC. 1990. Official Methods of Analysis. Vol. 1. 15th ed. Assoc. Off. Anal. Chem., Arlington, VA. 
Aviram, M., N. Volkova, R. Coleman, M. Dreher, M. K. Reddy, D. Ferreira, and M. Rosenblat. 2008. Pomegranate phenolics from the peels, arils, and flowers are antiatherogenic: Studies in vivo in atherosclerotic apolipoprotein E-deficient (E0) mice and in vitro in cultured macrophages and lipoproteins. J. Agric. Food Chem. 56:1148-1157.

Broderick, G. A., R. J. Wallace, and E. R. Ørskov. 1991. Control of rate and extent of protein degradation. Pages 541-592 in Physiological Aspects of Digestion and Metabolism in Ruminants, Proc. 7th Int. Symp. Ruminant Physiol. T. Tsuda, Y. Sasaki, and R. Kawashima, ed. Academic Press Inc., San Diego, CA.

Brown, M. V., M. S. Schwalbach, I. Hewson, and J. A. Fuhrman. 2005. Coupling 16S-ITS rDNA clone libraries and automated ribosomal intergenic spacer analysis to show marine microbial diversity: Development and application to a time series. Environ. Microbiol. $7: 1466-1479$

Chirumbolo, S. 2011. Plant polyphenolic compounds as potential antimicrobial drugs. J. Med. Microbiol. 60:1562-1563.

Dehority, B. A. 2003. Rumen Microbiology. Nottingham University Press, Nottingham, UK.

Fisher, M. M., and E. W. Triplett. 1999. Automated approach for ribosomal intergenic spacer analysis of microbial diversity and its application to freshwater bacterial communities. Appl. Environ. Microbiol. 65:4630-4636.

Gil, M. I., F. A. Tomas-Barberan, B. Hess-Pierce, D. M. Holcroft, and A. A. Kader. 2000. Antioxidant activity of pomegranate juice and its relationship with phenolic composition and processing. J. Agric. Food Chem. 48:4581-4589.

Gracious Ross, R., S. Selvasubramanian, and S. Jayasundar. 2001. Immunomodulatory activity of Punica granatum in rabbits. A preliminary study. J. Ethnopharmacol. 78:85-87.

Hammer, Ø., D. A. T. Harper, and P. D. Ryan. 2001. PAST: Paleontological Statistics Software Package for Education and Data Analysis. Palaeontol. Electron. 4. Accessed May 27, 2012. http:// palaeo-electronica.org/2001_1/past/past.pdf.

Jami, E., and I. Mizrahi. 2012a. Composition and similarity of bovine rumen microbiota across individual animals. PLoS ONE 7:e33306.

Jami, E., and I. Mizrahi. 2012b. Similarity of the ruminal bacteria across individual lactating cows. Anaerobe 18:338-343.

Kovacs, A., K. Yacoby, and U. Gophna. 2010. A systematic assessment of automated ribosomal intergenic spacer analysis (ARISA) as a tool for estimating bacterial richness. Res. Microbiol. 161:192197.

Kulkarni, A. P., S. M. Aradhya, and S. Divakar. 2004. Isolation and identification of a radical scavenging antioxidant-punicalagin from pith and carpellary membrane of pomegranate fruit. Food Chem. 87:551-557.

Lippke, H., W. C. Ellis, and B. F. Jacobs. 1986. Recovery of indigestible fiber from feces of sheep and cattle on forage diets. J. Dairy Sci. 69:403-412.

Makkar, H. P. S. 2003. Effects and fate of tannins in ruminant animals, adaptation to tannins, and strategies to overcome detrimental effects of feeding tannin-rich feeds. Small Rumin. Res. 49:241-256.

Miron, J., E. Yosef, E. Maltz, and I. Halachmi. 2003. Soybean hulls as a replacement of forage neutral detergent fiber in total mixed rations of lactating cows. Anim. Feed Sci. Technol. 106:21-28.
Murthy, K. N., V. K. Reddy, J. M. Veigas, and U. D. Murthy. 2004. Study on wound healing activity of Punica granatum peel. J. Med. Food 7:256-259.

Navarro, V., M. L. Villarreal, G. Rojas, and X. Lozoya. 1996. Antimicrobial evaluation of some plants used in Mexican traditional medicine for the treatment of infectious diseases. J. Ethnopharmacol. 53:143-147.

NRC. 2001. Nutrient Requirements of Dairy Cattle. 7th rev. ed. Natl. Acad. Sci., Washington, DC.

Oliveira, R. A., C. D. Narciso, R. S. Bisinotto, M. C. Perdomo, M. A. Ballou, M. Dreher, and J. E. P. Santos. 2010. Effects of feeding polyphenols from pomegranate extract on health, growth, nutrient digestion, and immunocompetence of calves. J. Dairy Sci. 93:4280-4291.

Patra, A. K., and J. Saxena. 2010. A new perspective on the use of plant secondary metabolites to inhibit methanogenesis in the rumen. Phytochemistry 71:1198-1222.

Reed, J. D. 1995. Nutritional toxicology of tannins and related polyphenols in forage legumes. J. Anim. Sci. 73:1516-1528.

SAS Institute. 1996. SAS/STAT Software Changes and Enhancements. SAS Inst. Inc., Cary, NC.

Shabtay, A., H. Eitam, Y. Tadmor, A. Orlov, A. Meir, P. Weinberg, Z G. Weinberg, Y. Chen, A. Brosh, I. Izhaki, and Z. Kerem. 2008. Nutritive and antioxidative potential of fresh and stored pomegranate industrial byproduct as a novel beef cattle feed. J. Agric. Food Chem. 56:10063-10070.

Singleton, V. L., R. Orthofer, and R. M. Lamuela-Raventos. 1999. Analysis of total phenolics and other oxidation substrates and antioxidants by means of Folin-Ciocalteu reagent. Methods Enzymol. 299:152-178.

Stevenson, D. M., and P. J. Weimer. 2007. Dominance of Prevotella and low abundance of classical ruminal bacterial species in the bovine rumen revealed by relative quantification real-time PCR. Appl. Microbiol. Biotechnol. 75:165-174.

Tilley, J. M. A., and R. A. Terry. 1963. A two-stage technique for the in vitro digestion of forage crops. J. Br. Grassl. Soc. 18:104-111.

Tzulker, R., I. Glazer, I. Bar-Ilan, D. Holland, M. Aviram, and R. Amir. 2007. Antioxidant activity, polyphenol content, and related compounds in different fruit juices and homogenates prepared from 29 different pomegranate accessions. J. Agric. Food Chem. 55:9559-9570.

Van Soest, P. J., J. B. Robertson, and B. A. Lewis. 1991. Methods of dietary fiber, neutral detergent fiber, and non-starch polysaccharides in relation to animal nutrition. J. Dairy Sci. 74:3583-3597.

Walter, J., G. W. Tannock, A. Tilsala-Timisjarvi, S. Rodtong, D. M. Loach, K. Munro, and T. Alatossava. 2000. Detection and identification of gastrointestinal Lactobacillus species by using denaturing gradient gel electrophoresis and species-specific PCR primers. Appl. Environ. Microbiol. 66:297-303.

Welkie, D. G., D. M. Stevenson, and P. J. Weimer. 2010. ARISA analysis of ruminal bacterial community dynamics in lactating dairy cows during the feeding cycle. Anaerobe 16:94-100.

Zhou, M., E. Hernandez-Sanabria, and L. L. Guan. 2009. Assessment of the microbial ecology of ruminal methanogens in cattle with different feed efficiencies. Appl. Environ. Microbiol. 75:6524-6533. 